\title{
Food and feeding ecology of the MUDSKIPPER Periopthalmus koelreuteri (PALLAS) Gobiidae at Rumuolumeni Creek, Niger Delta, Nigeria
}

\author{
F.G. Bob-Manuel \\ Rivers State University of Education, Rumuolumeni, P. M. B. 5047, \\ Port Harcourt, Nigeria
}

\begin{abstract}
The food habits of the mudskipper Periophthalmus keolreuteri (Pallas) from the mudflats at Rumuolumeni Creek, Niger Delta, Nigeria were studied. The frequency of occurrence and 'point' methods was used for the gut content analysis. The results indicate that the juveniles were herbivorous feeding more on aquatic macrophytes, diatoms and algal filaments while the adults had a dietary shift towards crustaceans, aquatic and terrestrial insects and polychaetes. The amphibious lifestyle of the mudskipper confers on it the trophic position of a zoobenthivore and a predator.
\end{abstract}

\begin{abstract}
Keywords: diet composition, mudskippers, food web, trophic relations, Niger Delta. INTRODUCTION

The mudskippers Periophthalmus koelreuteri (Gobiidae: Oxudercinae) live in the intertidal habitat of the mudflats and in mangrove ecosystem (Murdy, 1989). These fishes are uniquely adapted to a completely amphibious lifestyle (Graham, 1997). They are quite active when out of water, feeding and interacting with one another and defending their territories. The mudskippers, Periophthalmus koelreuteri (Pallas) have a range of peculiar behavioural and physiological adaptations to an amphibious lifestyle. These include anatomical and behavioural adaptations that allow them to move

catch bigger fishes. The rich food supplies in the mangrove mud flat have been the impetus which led the goby-like ancestors of modern mudskippers to leave the water from time to time. (Evans et al., 1999) The mudskippers can move rapidly on the mud, which is inaccessible to people.

The mudskipper, $P$. koelreuteri is a residential fish inhabiting the mudflats of the Niger Delta estuaries, the waterways, and the mangrove forests in Nigeria. The objective of this work is to investigate the food and feeding ecology of the mudskipper $P$. koelreuteri in the mudflat of the Rumuolumeni creek in the Niger Delta, Nigeria.
\end{abstract} effectively on land as well as in the water (Harris, 1960) the ability to breathe through their skin and the lining of their mouth (the mucosa) and throat (the pharynx) by means of cutaneous air breathing (Graham, 1997), digging of deeps burrows in soft sediments that allow the fish to thermo-regulate (Tytler and Vaughan, 1983); avoid marine predators during high tide when the fish and burrow are submerged (Sasekumar et al 1994)

The mudskipper, $P$. Koelreuteri in widely fascinating of all tropical fish. They can be seen jumping, climbing, and skipping about with great agility in the mangrove creeks of the Niger Delta region of Nigeria. These fish have no legs but move with their arm-like pectoral fins. The mudskippers are widely distributed in the brackish water rivers, creeks, and lagoons in the Niger-Delta area of Nigeria. This fish is economically important and actively fished by the local inhabitants of this area to whom it serves as a special delicacy. The fish is also used as bait to

\section{MATERIALS AND METHODS}

Study Site: The study site was the mangrove swamp and mudflat at the Western end of the Rivers State University of Education Rumuolumeni, Port Harcourt. The vegetation of the Rumuolumeni Mangrove Creek consist of the red mangrove Rhizophora racemosa and the white mangrove Avicennia Africana with heights ranging from 2.50 to $5.60 \mathrm{~m}$. The main river bifurcates into two smaller tributaries. The water is brackish. At low tide stilt-like prop roots of the mangrove were visible; the intertidal mudflats were exposed and served as feeding ground for the mudskippers. Burrows and small holes between 3.5$6 \mathrm{~cm}$ in diameter abound around the prop-roots of the Rhizophora trees. These areas served as Periophthalmus. species hide out. Traps were set around these areas. The substrate consisted of hydromorphic soil of the marine alluvium type heavily impregnated with products of decayed organic 
matter, usually mud. This gives the soil a black coloration, water logged substratum and the smell of a rotten odour.

Fish Trapping Method: About 405 mudskippers which consisted of 250 juveniles and 155 adults were collected with standard lengths ranging from 6.20 $6.30 \mathrm{~cm}$ and $6.30-15.0 \mathrm{~cm}$ respectively. The fish were obtained between March 2009 to August 2009 on weekly basis.

The fishing gear used were basket traps woven with cane material with a single conical incurving opening. Each basket trap is $30 \mathrm{~cm}$ long and $35 \mathrm{~cm}$ wide. These traps are non-selective and can catch both adults and juveniles. The traps were set during the low-tide. Crushed crabs such as Cardiosoma armatum (land crab) and Uca tangeri (fiddler crab) were used as bait for the traps. As soon as catches were made, the specimens were removed and put into specimen bottles containing $4 \%$ formalin. These were later taken to the Biology laboratory of the Rivers State University of Education Port Harcourt for analysis.

Laboratory Analysis: In the laboratory, the fish were separated into adults and juveniles. The total and standard lengths of the specimens were measured to the nearest millimeter using a measuring board. The stomach and some part of the oesophagus were dissected out in each specimen and placed in a glass petridish containing some freshwater to neutralize the effect of the formalin for a short while. Each stomach was then slit open and the content removed by scrapping the inner mucosa with a spatula. The weight of the contents was now taken and food items identified. This was done by spreading out the food items over a slide, a little at a time. Two drops of water was added to spread out the food contents. Finally, the number of each taxonomic entity was recorded on data sheet for each stomach.

Two methods were used for the stomach content analysis. The frequency of occurrence method and the 'point' method. The occurrence method (Hynes 1950 and Frost, 1943). The occurrence method is one in which the relative importance (to the fish) of different food items in each stomach were identified and recorded. Here the number of fish in which each food item occurred was recorded and expressed as a percentage of the total number of stomach examined. This method being qualitative portrays which organisms were best being used as food.

The subjective or 'points' method was first employed by (Swynnerton and Worthinton 1940) and has since been used by other workers(Frost, 1943; Hynes, 1950; Fagade, 1971). Here each food item is awarded point proportional to its estimated contribution to stomach volume. A total of 100 points is awarded to all the content of stomach and these points shared among the contents taking cognizance of the relative volume of each food item. Fagade (1971) used only stomachs that are more than half filled. The points gained by each food from all the stomachs examined are summed up and expressed as a percentage of the total number of points. A combination of these two methods was used so that one method could nullify the disadvantage of the other.

RESULT: The analysis of the gut-content for juvenile Periophthalmus koelreuteri using the frequency of occurrence method is shown in Table 1.

Table I. Gut-content analysis of juvenile Periophthalmus koelreuteri in Rumuolumeni Creek

\begin{tabular}{|l|c|c|}
\hline Food Items & $\begin{array}{l}\text { Number of Species in which } \\
\text { food items occurred }\end{array}$ & Frequency of occurrence (\%) \\
\hline Diatoms & 213 & 85.00 \\
\hline Fragments of Higher Plants & 227 & 15 \\
\hline Crustacean appendages & 38 & 10.30 \\
\hline Fish Scales & 26 & 61.90 \\
\hline Sand Grains & 155 & 43.00 \\
\hline Unidentified Organic Matter/detritus & 108 & 80.60 \\
\hline Algal Filament & 201 & 12.50 \\
\hline Fish Gills & 31 & 25.00 \\
\hline Polychaetes & 63 & 30.00 \\
\hline Insect parts & 75 & \\
\hline No. of specimens & 250 & \\
\hline Stomach length range & $4.60-6.20 \mathrm{~cm}$ & \\
\hline
\end{tabular}

The gut-content analysis of juvenile P. koelreuteri using the ‘Point' method is shown in Table 2. 
Agric. Biol. J. N. Am., 2011, 2(6): 897-901

Table 2. Gut-content analysis of Juvenile $P$. Koelreuteri in Rumuolumeni creek using the 'Point' method

\begin{tabular}{|l|c|c|}
\hline Food Items & Point gained & (\%) of total \\
\hline Diatoms & 7,450 & 38.80 \\
\hline Fragments of Higher Plants & 9,500 & trace \\
\hline Crustacean Appendages & - & 1.2 \\
\hline $\begin{array}{l}\text { Fish Scales } \\
\text { Sand Grains }\end{array}$ & 300 & 4.4 \\
\hline $\begin{array}{l}\text { Unidentified Organic Matter } \\
\text { (detritus) }\end{array}$ & 1,100 & 23.6 \\
\hline Algal Filament & 5,900 & Trace \\
\hline Fish Gills & - & 1.4 \\
\hline Polychaetes & 350 & 1.1 \\
\hline Insect parts & 275 & \\
\hline Total Points & 25,000 & \\
\hline No. of Specimens & 250 & \\
\hline Standard Length range & $4.60-6.20 \mathrm{~cm}$ & \\
\hline
\end{tabular}

The analysis of gut-content using the frequency of occurrence method is shown in Table 3. for adult Periophthalmus koelreuteri.

Table 3. Gut-content analysis of Adult $P$. Koelreuteri in Rumuolumeni creek using the frequency of occurrence method

\begin{tabular}{|l|c|c|}
\hline Food Items & Point gained & (\%) of total \\
\hline Diatoms & 23 & 15.3 \\
\hline Fragments of Higher Plants & 31 & 20.2 \\
\hline Crustacean Appendages & 148 & 50.5 \\
\hline Fish Scales & 78 & 45.5 \\
\hline Sand Grains & 71 & 50 \\
\hline Unidentified Organic Matter/detritus & 78 & 27.3 \\
\hline Algal Filament & 42 & 80 \\
\hline Fish Gills & 78 & 85.4 \\
\hline Polychaetes & 134 & \\
\hline Insect parts & 132 & \\
\hline No. of Specimen & 155 & \\
Standard length & $6.30-15.0 \mathrm{~cm}$ & \\
\hline
\end{tabular}

The gut-content analysis of adult $P$. koelrenteri using the 'points' method is shown in table 4.

Table 4. Gut-content analysis of adult Periophthalmus koelreuteri at Rumuolumeni Creek using the 'Point' method.

\begin{tabular}{|l|c|c|}
\hline \multicolumn{1}{|c|}{ Food Items } & Points gained & Percentage of total \\
\hline Diatoms & - & trace \\
\hline Fragments of Higher Plants & - & 36.40 \\
\hline Crustacean appendages & 5,642 & 10.2 \\
\hline Fish Scales & 1,581 & 1.10 \\
\hline Sand Grains & 171 & 1.50 \\
\hline Unidentified Organic Matter/detritus & 233 & 1.30 \\
\hline Algal Filament & 202 & 6.50 \\
\hline Fish Gills & 1,008 & 20.70 \\
\hline Polychaetes & 3,209 & 22.30 \\
\hline Insect parts & 3,457 & \\
\hline Total Points & 15,000 & \\
\hline No. of Specimen & 155 & \\
\hline Standard Length range & $6.30-15.0 \mathrm{~cm}$ & \\
\hline
\end{tabular}




\section{AGRICULTURE AND BIOLOGY JOURNAL OF NORTH AMERICA}

ISSN Print: 2151-7517, ISSN Online: 2151-7525, doi:10.5251/abjna.2011.2.6.897.901

(C) 2011, ScienceHu $\beta$, http://www.scihub.org/ABJNA

\section{DISCUSSION}

By the occurrence method, the major food items were fragment of higher plants $(90.6 \%)$, algal filaments $(80.60 \%)$, diatoms (85\%), sand grains (61.9\%) unidentified organic matter or detritus (43.0\%).

From the point method, the most dominant food items for the juveniles were fragments of higher plants $(38.2 \%)$, diatoms $(29.8 \%)$, and algal filament (23.6\%). Also unidentified organic matter or detritus, sand grains, Polychaetes and insect parts occurred as incidental food items. It is evident that the juveniles of $P$. koelreuteri are herbivore. This agrees with the work of (Sarker et al 1980; Sarker et al 2006) who described the mudskipper Pseudapocryptes dentatus as a strict herbivore with (diatoms) phytoplankton dominating the food items. It could be inferred from the foregoing that the food of the juvenile mudskipper tilted toward plant materials from both frequency of occurrence method and the points method which range from fragments of higher plants, to diatoms and algal filament at the Rumuolumeni creek of the Nigerian Niger delta region.

The gut-content analysis of adult $P$. koelreuteri using the frequency of occurrence method indicate that the most important food items are crustacean appendages (95.5\%) Polychaetes (86.4\%) and insect parts (85\%). Other items which occurred less frequently include fish scales, detritus and fish gills (50\%) respectively as well as sand grains (45.5\%); The gut-content analysis using the 'Points' method for the adult $P$. koelreuteri showed that the most dominant food items are also crustacean appendages (36.40\%), Insect parts (22.30\%) and polychaetes $(20.7 \%)$. This is an indication that food items of animal origin are more important for the adult $P$. koelreuteri. This animal eating habit of the mudskipper is supported by the findings of (Sasekumer et al. 1994). It was also reported that the mudskipper is a carnivorous opportunistic feeder which feeds on small prey such as small crabs and other arthropods (Clayton 1993; Khairnorizam and Norma-Rashid, 2003; Piper Ross 2007; Jaafar et al; 2009). Moreover, only ten specimens were found with empty stomach which is an indication that the mudskipper is a regular feeder.

The change in diet from a herbivorous feeding habit to a carnivorous lifestyle was also observed to be associated with changes in growth such as increase in the gape of the mouth and the length of the gut.

In the two groups investigated (juvenile and adult), there is an indication that certain food items are preferred at certain stages in the life of the mudskippers and that it is a selective feeder

A critical look at the food consumed by these mudskippers makes it possible to present the trophic interrelationship. Since $P$. koelreuleri, feeds on aquatic insects and crustaceans which feed mainly on microphytes, plant remains and algal filaments, they are primary consumers making up the second trophic level,

Though $P$. koelreuteri feed on microphytes they feed more on tiny crustaceans which are primary consumers, they are therefore secondary consumers and in the third trophic level.

Furthermore, since $P$. koelreuteri also feed on juvenile fish (hence fish scales) and shrimps and minute crustaceans they are referred to as predators. As a result of this predation they may be placed at the fourth trophic level as tertiary consumers. In essence, $P$. koelreuteri is a predator since it has minute teeth and the various food items consumed testify to this. Basically, since $P$. koelreuteri are mud dwellers, they eat up the organisms available in the mud such as crustaceans (e.g. Sesarma spp), polychaetes, and filamentous algae. At high tide, the mudskipper perch on mangrove roots where it feeds on small fish.. During low-tide $P$. koelreuteri walk on the mud, hunting and catching its prey of insects and crustaceans. The mudskippers, $(P$. keolreuteri) are therefore predators occupying the position of secondary and tertiary consumers in the food chain which is determined by the sizes and types of food items available.

Also the trophic position of the mudskippers is similar to those of other zoobenthivore fish species but there seem not to be competition with other zoobenthivores. This is due to the amphibious lifestyle of the mudskippers which provides access to a rich source of mangrove crabs which is not accessible to other fish and thus gives the mudskipper, added advantage to its feeding ecology. The findings of this research has thrown some light as to the food and feeding habits of the mudskipper and thus afford fish culturist an insight into the culture of $P$. koelreuteri.

\section{REFERENCES}

Clayton, D.A. (1993). Mudskippers. Oceanography and Marine Bulletin: An Annual Review, 31: 507 - 577

Evans, D.H. Claiborne, J.B. and Kormanik, G.A. (1999). Osmoregulation, acid-base regulation, and nitrogen excretion. In; Horn, M.H. Martin K.I.M., Chotkowski, 
M.A. (eds). Interidal Fishes: Life in Two Worlds: Academic Press, San Diego.

Fagade, S.O. (1971). The food and feeding habits of tilapia species in the Lagos Lagoon J. Fish. Biol. 3: 151 156.

Fagade, S.O., and Olaniyan, C.I.O. (1973). The Food and Feeding Interrelationships of the Fishes in the Lagos Lagoon. J.Fish Biol. 5: $205-226$.

Frost, W.E. (1943). The natural history of the minnow. Phoxenus phoxenus. J. Anim. Ecol. 12: 139 - 162.

Graham, J.B. (1997). Air-breathing Fishes. Evolution, Diversity, and adaptation. Academic Press. San Diego.

Harris, V.A. (1960). On the locomotion of the Mudskipper Perophthalmus koelreuteri (Pallas); Gobiidae. Proceedings of the zoological society of London 134: 107-135.

Hynes, H. B. N. (1950). The food of freshwater sticklebacks Gaterosteus aculeatus and Pygasteus puugitus with a review of methods used in studies of the food of the fishes. J. Anim. Ecol. 19:35 -58.

Hyslop, E. J. (1980). Stomach content analysis. A review of methods and their application. J. Fish Biol., 17: 411 -429 .

Ishimatsu, A., Hishida, Y., Takita, T., Kanda, T., Oikawa, S., Takeda, T. and Khoo, K.H. (1998). Mudskipper store air in their burrows. Nature, 391: 237 - 238.

Ishimatsu, A., Yoshida., Itoki N., Takeda, T., Lee, H.J. and Graham, J.B. (2007) Mudskippers brood their eggs in air but submerge them for hatching. The Journal of experimental Biology, 210: 3946 - 3954

Jaafar, Z. Lim, K.K. P, and Chou, L.M. (2006). Taxonomical and morphological notes on two species of mudskippers, Periophthalmus walailakae and Periophthalmodon schlosseri (Teleostei: Gobiidae) from Singapore. Zoological Science. 23 : 1043 -1047.
Jaafar, Z., Perrig, M. and Chou, L. M. (2009). Periophthalmus variabilis (Teleostei: Gobiidae: Oxudercinae), a valid species of mudskipper, and a rediagnosis of Periophthalmus novemradiatus. Zoological Science 26: 309 - 314.

Khaironizam, M. Z. and Norma-Rashid, Y. (2003). First record of the mudskipper, Periophthalmodon septemradiatus (Hamilton) (Teleostei: Gobiidae) from Penmsular Malaysia. The Raffles Bulletin of Zoology, 51 (1) : $97-100$.

Murdy, E.O. (1989). A Taxonomic Revision and Cladistic Analysis of the Oxudercine Gobies (Gobiidae: Oxudercinae). Records of the Australian Museum Suppl. U: 1-93.

Piper, Ross (2007). Extraordinary Animals. An Encyclopedia of Curious and unusual Animals. Greenwood Press.

Sarker, A.L.; Al-Daham, N. K, and Bhatti, M.N. (1980). Food habits of the mudskippers, Periophthalmus dentatus. J. Fish, Biol. 17, $635-637$.

Sarker, A.L., Al-Daham, N.K., Blaatti, M.N. (2006). Food habits of the mudskipper, Pseudapocryptes dentatus (Val.). Journal of Fish Biol. 17: 635 - 639

Sasekumar, A.; Chong, V.C.; Lim, K.H. and Singh, H.R. (1994). The Fish Community of Matang Mangrove Waters, Malaysia. In: Sadara, S.; Wilkinson, C.R.; Chou, L.M. (eds). Proceedings, Third ASEAN Australia Symposium on Living Coastal Resources Research papers. Bangkok, Thailand; Chulalonghorn University. Pp. vol. 2: $457-464$.

Swynnerton, G.H. and Worthington, E. B. (1940). Note on the food of fish. J. Anim. Ecol. 9:183 - 187

Tytler P. and Vaughan T, (1983). Thermal Ecology of the Mudskippers Periophthalmus boddaerti (Pallas) of Kuwait Bay. Journal of Fish Biology 23 (3): 327 - 337. 